\title{
The Development of Modern Art in Mongolia: On the Example of Mongolian Modern Painting of the Late Twentieth and Early Twenty-First Centuries
}

Selenge Tumur-ochir

Mongolian State University of Education,

Ulaanbaatar, Mongolian People's Republic.

(iD) https://orcid.org/0000-0002-3255-0037, e-mail: selenge@msue.edu.mn

\begin{abstract}
Modern art in Mongolia has been developing since the last century. The art appeared as a result of artists' ideas, expression of national mentality and other factors. As some researches said: "Mite of the abstract paintings were established in Hun states, because when this times, all of the people to the painted effect of their mind on the rock of cave" on their tractate book. That says that the abstract paintings was established at that time, but according to other sources it was developed in 1960. For example, in 1968 Mongolian young painters organized an exhibition named: the first exhibition of young painters. Then, in 1980 modern and contemporary arts started developing. The purpose of the study is to analyze the development and classification of modern art in the late twentieth and early twenty-first centuries, which are kept in art galleries. The study was conducted in the following steps: to study modern Mongolian art and to identify current trends in its evolution. The study classified 2,333 paintings. Consequently the next conclusions were drawn: abstractionism, postimpressionism, and im-pressionism were more developed in modern paintings created in 1990-2000. Modern paintings created in 2000-2009, on the other hand, were more developed in abstraction, fauvism, surrealism, and symbolism. This shows that modern Mongolian artists prefer abstract and symbolic paintings. Before 1990, there was a lot of realism, but since 1990, modernism has developed a lot and has become a major trend.
\end{abstract}

Keywords: modern Mongolian paintings, development, analyze, classification.

For citation: Tumur-ochir S. (2021). The Development of Modern Art in Mongolia: On the Example of Mongolian Modern Painting of the Late Twentieth and Early Twenty-First Centuries. Etnicheskaya kultura = Ethnic Culture, 3(3), 15-19. DOI:10.31483/r-98686.

\section{Развитие современного монгольского искусства: на примере современной монгольской живописи конца XX - начала XXI вв.}

\author{
Тумур-Очир C. \\ Монгольский государственный педагогический университет \\ Улан-Батор, Монгольская Народная Республика. \\ https://orcid.org/0000-0002-3255-0037, e-mail: selenge@msue.edu.mn
}

\begin{abstract}
Резюме: Модернистская живопись начала развиваться в Монголии в прошлом веке. Она являет собой результат измышлений художников, выражение национального менталитета и других факторов. Согласно некоторым исследователям, малая доля абстрактной живописи зародилась в Гуннах, именно в то время люди начали изображать продукты мышления на стенах пещер. Исходя из вышесказанного, можно сделать вывод, что в то время была сформирована абстрактная живопись, хотя, согласно другим источникам, она зародилась в 1960-х. К примеру, в 1968 молодые художники из Монголии организовали «первую выставку молодых художников». В 1980-х начала развиваться модернистская и современная живопись. Цель исследования - анализ живописных работ конца XX - начала XXI вв., хранящихся в художественных галереях Монголии. Исследование предполагало решение таких задач, как изучение современного монгольского искусства и установление актуальных тенденций в его эволюции. Исследованием охвачено 2333 картины. В результате автор пришел к следующим выводам: в живописи 1990-2000 гг. более развиты абстракционизм, импрессионизм и постимпрессионизм. Картины же, созданные в 2000-2009 гг., в большей степени тяготеют к фовизму, сюрреализму и символизму. Современные монгольские художники предпочитают абстрактные и символические картины. До 1990 г. было много реализма, но с 1990 г. модернизм сильно развился и стал основным трендом.
\end{abstract}

Ключевые слова: современная монгольская живопись, развитие, анализ, классификация.

Для цитирования: Тумур-Очир С. Развитие современного монгольского искусства: на примере современной монгольской живописи конца XX - начала XXI вв. // Этническая культура. - 2021. - Т. 3, №3. - C. 15-19. DOI: 10.31483/ r-98686.

\section{Introduction}

In the twentieth century Mongolian art was more developed in thematic, portrait, nature, and life themes, and modernism flourished. In the late 1960s, abstract and Impressionism began to appear in Mongolian art. The features of the works varied, and most of them rewrote the Mongolian tradition. Since the 1970 s, the development of Mongolian art has been based on many trends, including fauvism, symbolism, surrealism, and cubism. It is gratifying that modern painting has been fully accepted since the 1980s. It can be understood that the competition of modern artists has started with the opening of open and closed paintings in a closed society. This is because it has been difficult to keep up with the evolutionary trend of glass painting since the 1990s. It was unclear who was drawing in which direction. They were considered by art critics to be «mind-boggling» paintings.

Therefore, this study was started in 2017. 224 paintings at the Mongolian National Gallery of Art from 2017-2019 were analyzed. The reason for choosing the topic was that most professionals and non-professionals did not know about modern paintings and their classification. Art critics have not studied much about the classification of modern Mongolian art. However, the development of art 
has been studied extensively. For example, Mongolian and Soviet researchers have done a lot of research. In 1970, the publication of the magazine «Fine Arts» became a major contribution to the study of fine arts in Mongolia. In 1975, a research institute was established and a brief history of Mongolian fine arts was being developed. At that time, not only Mongolian scholars but also foreign Mongolian scholars and researchers studied Mongolian fine arts.

A brief account of the study of modern Mongolian art:

Most of them were researchers from the Russian Federation. For example, researchers such as N.N. Belsky, K.V. Vyakina, S.V. Kiselev studied Mongolian fine arts. They wrote a study of early art painting. Researching journalist I.I. Lomakina also studied the state of Mongolian fine arts in the twentieth century in her work «The Visual Art of Socialist Mongolia». O.I. Galerina, on the other hand, is unique in that she provides an overview of Mongolian fine arts.

In 1980, researchers L. Sonomtseren, S. Luvsanvandan, L. Batchuluun, D. Dashbaldan, T. Galbadrakh, B. Badrakh, and D. Maidar conducted a review of Mongolian fine arts, issues of tradition and innovation, types, and folk art. There are books and scholarly articles on the fine arts written by these scholars, that includes articles on modern art.

Researcher L. Sonomtseren's book «Mongolian Fine Arts» aims to study and summarize the historical development of fine arts in the democratic stage of the revolution. He also wrote realistic paintings of 1921-1940 under the policy of the Mongolian People's Party. D. Dashbaldan, an art critic, wrote the book «Modern Art» in combination with the artist's skills and introduced the main representatives of modern world art trends. Researcher N. Tsultem also wrote an article entitled «New Mongolian Fine Arts» in which he praised the contributions of senior Mongolian artists.

The first half of the twentieth century was entirely within the confines of the ideology of socialist realism. At the end of the twentieth century, however, modern paintings and articles about them became popular. Since the 21 st century, art critics Ts. Uranchimeg, O. Sosor and Ts. Erdenetsog has written books and essays on contemporary art. Uranchimeg. Ts wrote the term modern art in her book. Erdenetsog. Ts explained the colors of modern art, while Sosor.O wrote about the history of art.

\section{Methods}

This study was created by qualitative research method. In the study, the works were carried out in the style of realism and modernism.

The study is aimed to examine the artist and their works between the years 1990-2009 using the method of artistic criticism.

A study of the classification of modern paintings: examples of works in the collection of the Mongolian Art Gallery. The Mongolian Art Gallery is a public service organization established in 1991. Since the victory of the People's Revolution of 1921, the gallery has more than 4,000 works of art created by talented artists of all generations, including paintings, sculptures, carvings and embroidery.

\section{Results and Discussion}

Modernism (Italian modernismo-modern), in Latin modernus means modern, new generation.

Modern fine arts originated in the world in the late 19th and early 20th centuries. American and European art critics have differing views on the term «modernism». American art critics believe that it began in the early 19th century with classicism, while European art critics believe that modern art began with impressionism [1]. For example, art historian and mathematician Richard Dedekind (18311916) and Ledwig Boltzmann (1844-1906) believe that modernism began in the 1870 s. Researcher Everdell traces the origins of modern art to a painting by Seurat painted in 1885-1886. Clement Greenberg, on the other hand, says that it originated in Immanuel Kant's (1724-1804) work, The First True Modernist.

Austria Eyesteinsson notes that «modernism began in the early 1800 s with romanticism, realism in the 1830 s, and the first impressionist show in 1874». American art critic John Elder field believes that «modern art dates back to the early nineteenth century or the period of classicism». «Modern art has its roots in impressionism», says Reads [2].

Brief introduction of the origins of modern Mongolian painting.

Mongolian paintings are derived from ancient rock paintings. Totem idols and animal images have evolved from paintings, and images of Buddhas have appeared on paper.

Painting was highly developed in the arts and culture of the first states of Mongolia, such as the Huns, Xiambi, and Zhujiang.

Later, in the Middle Ages, the works of Undur Gegeen Zanabazar became famous for their craftsmanship. Socialrealist paintings have been developing since the twentieth century. It is directly related to the government of that time. In the same century, modern painting began to develop in Mongolia (pic. 1).

- Since the 1920 s social-realist painting copies party and
government policies

Fig. 1. Development of Mongolian fine art in 1920-1940 [3]

Рис. 1. Развитие монгольского изобразительного искусства в 1920-1940 годах

In this study, Modern categorizes the development of art as follows: 1) beginning period (1950-1970); 2) development period (1970-2000); 3) from modernism to postmodernism (2000-2010).

At the beginning of 1968, the «First Exhibition of Young Artists» was opened in the exhibition hall of the Mongolian Craftsmen's Union. That exhibition became the basis for the development of modern Mongolian art [3]. In this exhibition: O. Tsevegjav's «Mother's White Heart», B. Soosai's «Mother», «Atak», «Lullaby», P. Baldandorj's «Lake Hövsgöl», «Still life» G. Dunburee's «Modern goat» spread. However, the Central Committee of the Mongolian 
People's Revolutionary Party issued a resolution to close the exhibition, accusing the paintings of promoting bourgeois ideology. At that time, only a few genres of art were developing: wealth, history, and portraiture.

One of the first abstract paintings in Mongolia is «Mother's White Heart» by O. Tsevegjav (pic. 2).

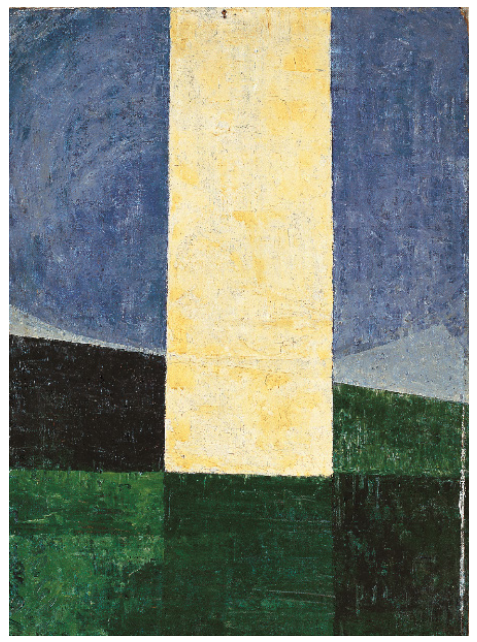

Fig. 2. Tsevegja O. «Mother's White Heart» (1968). Mongolian National Modern Art Gallery

Рис. 2. О. Цевегджав “Белое сердце матери”. Монгольская национальная галерея современного искусства

One of the first abstract paintings in Mongolia is «Mother's White Heart» by O. Tsevegjav. Artist O. Tsevegjav's painting «Mother's White Heart» is unique in that it shows the inner heart of a mother in geometric shapes and colors. The bottom of the paiting is painted green to symbolize the earth. In the center of the painting is a white square, a symbol of the mother's pure white heart. The top of the picture is painted in blue and symbolizes the sky.

The artist is unique in his work: he abstractly depicts the love of the mother and the connection with the earth.

Artist A. Adyaabazar is one of the artists who was developing Mongolian Cubism. His paintings depict Mongolian tradition using Cubist art. There are many paintings, and the painting «Mongolian Queen» was introduced. Painted in cool colors, this painting uses geometric elements and is known for its color dissolution and design (pic. 3).

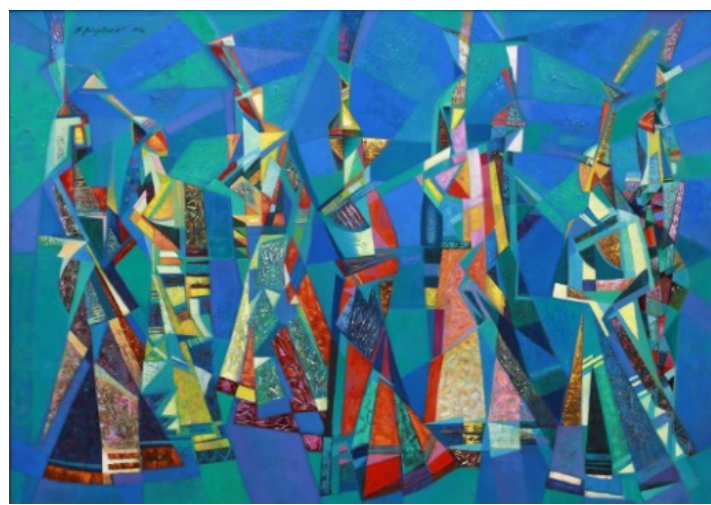

Fig. 3. Adyabazar.A «Mongolian Queen» (1992). Mongolian National Modern Art Gallery

Рис.3. Адьябазар."Монгольская королева" (1992). Монгольская национальная галерея современного искусства
Artist Ts. Enkhjargal's paintings are abstract and brightly colored. In other words, he is an artist who has created an abstract design with a healing image and hidden meaning that can only be imagined in the mind. That's why he became known as a Mongolian surrealist artist. The artist's painting «Eternal» was praised at the time (pic. 4.)

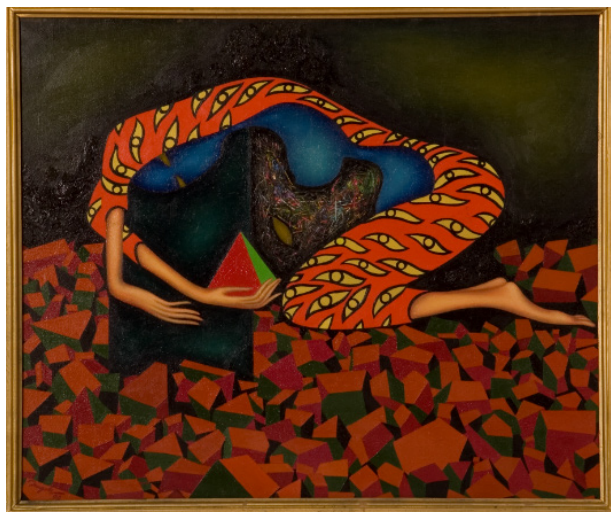

Fig. 4. Enkhjargal.Ts «Eternal» (1990). Mongolian National Modern Art Gallery

Рис. 4. Энхьяргал Ц. “Вечный” (1990). Монгольская национальная галерея современного искусства

Since 2000, cubism, expressionism, impressionism, abstractionism, surrealism, fauvism, realism and futurism have been developing in Mongolia. Nowadays, the art of surrealism and symbolism, which expresses traditional Mongolian paintings with its own solutions, color schemes; and cubist paintings, using basic geometric shapes and expressions of hidden dreams and consciousness, are developing.

Classification of Mongolian modern art. A total of 720 works drawn before 2010 were classified using realistic visual methods.

The study of realist paintings includes: 157 portraits, 331 landscapes, 171 welfare paintings, and 61 other works (pic. 5).

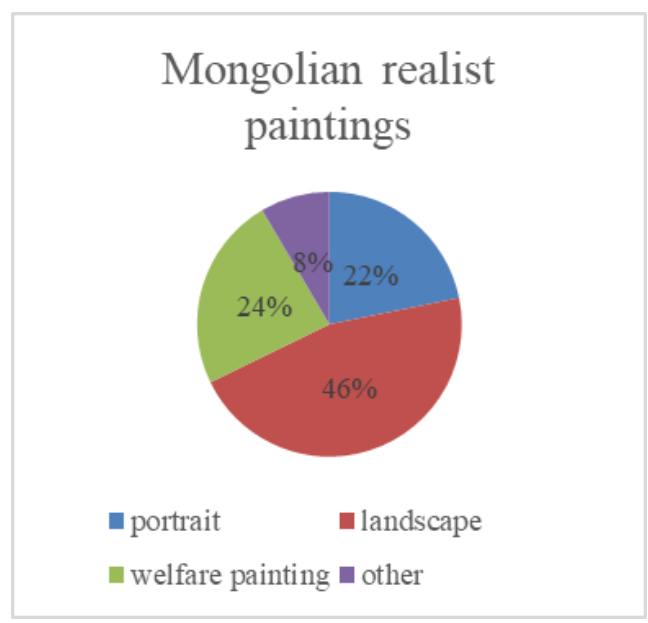

Fig. 5. Classification of Mongolian realist painitngs. Mongolian National Modern Art Gallery

Рис. 5. Классификация монгольских картин в направлении реализма. Монгольская национальная галерея современного искусства

According to research, natural painting accounts for a higher percentage. As a result of a detailed study of the graphic above, the features of realistic painting are:

1. The artists chose a subject that addresses the most important issues of the time, aimed at educating the masses 
in the ideology of the revolution. These works, which praised the ideology of the revolution, were closely linked to socio-political policy.

2. The subject of fine arts at that time was a socialrealist depiction of the labor, life, party policies, and social changes of the common people. Artits also used traditional oil painting techniques with modern themes.

3. Portraits of famous politicians, good herders, labor heroes, famous artists, and actors occupy a prominent place.

4. Colors and expressions of natural beauty occupy a large part of the art gallery.

5. Pictures of Abstract Thought - Mongolian traditional rituals, abstract concepts, geometric representations, and colors were used to express many things.

Images of abstract thought include modern and contemporary arts. Modern art was studied thoroughly in the works of 1990-2009.

To study the development of modern art in detail, two types of research were conducted: 1990-2001 and 2002-2009.

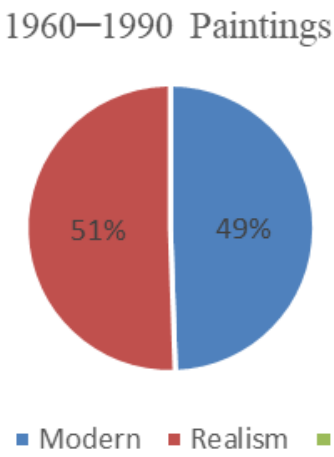

Fig. 6. Classification of Mongolian painitngs in 1960-1990. Mongolian National Modern Art Gallery

Рис. 6. Классификация произведений монгольской живописи в 1960-1990 гг. Монгольская национальная галерея современного искусства

This is because in 1950-1990 modern painting accounted for a very small percentage, while in 1960-1990 it accounted for the same percentage.

For example, to study the development of Mongolian art in 1950-1990, a total of 1197 paintings were classified into modern and realistic (modernism - 592 paintings, realism - 605) (pic. 6).

The development of the art has been periodically studied in detail since 1990. From 1990 to 2001, 169 paintings were examined (modern painting -126 , realism -43 ).

In the 1991-2001 survey, 75 percent of the paintings were modern paintings, which means that modernism began to develop in Greater Mongolia in the 1990s. An attempt to categorize this year's contemporary paintings by the mainstream was undertaken (pic. 7,8 ): abstract 43, impressionism - 16, cubism -4 , fauvism -9 , surrealism -6 , expressionism - 3, neo-expressionism - 9, post-impressionism -31 .

Studies show that post-impressionism, abstract and impressionist currents account for the largest share. Postimpressionism is more developed than the following four currents. These include: 1) symbolism; 2) nabism; 3) Pont Avenue school; 4) synthetism (pic. 8).

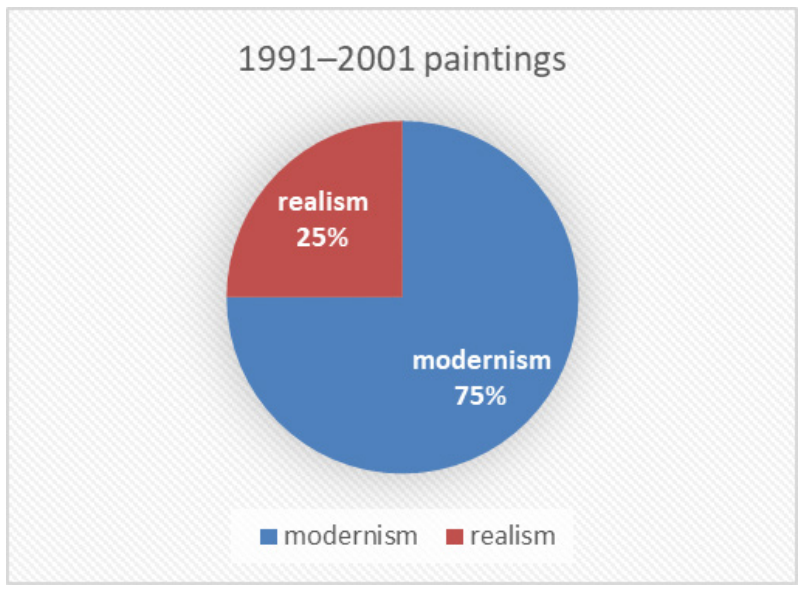

Fig. 7. Classification of Mongolian painitngs in 19912001. Mongolian National Modern Art Gallery

Рис. 7. Классификация произведений монгольской живописи в 1991-2001 гг., Монгольская национальная галерея современного искусства

Symbolism's predominance in these four sects is a clear example of Mongolians' respect for and value of their traditions. It has been observed in the course of the research

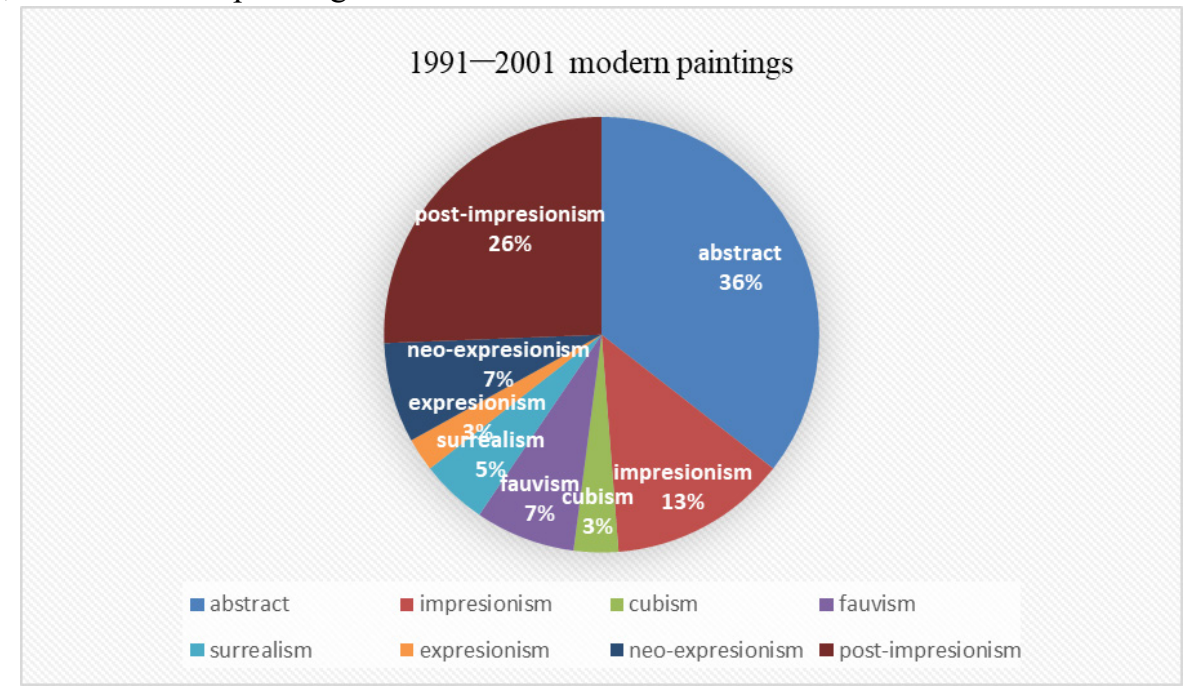

Fig. 8. Classification of Mongolian modern painitngs in 1991-2001. Mongolian National Modern Art Gallery

Рис. 8. Классификация произведений монгольской современной живописи в 1991-2001 гг., Национальная галерея современного искусства Монголии 


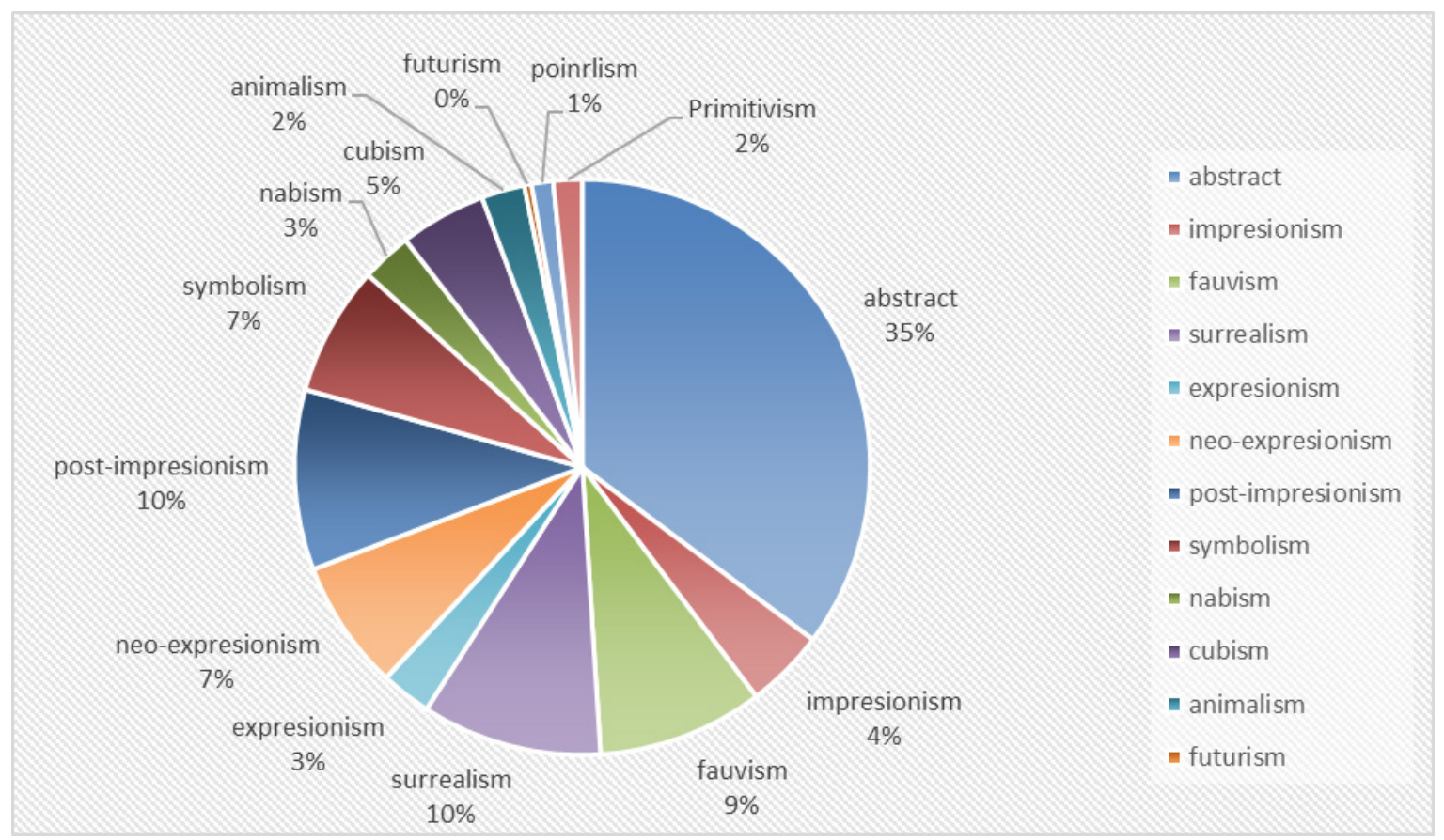

Fig. 9. Classification of Mongolian modern painitngs in 2000-2009. Mongolian National Modern Art Gallery

Рис. 9. Классификация произведений монгольской современной живописи в 2000-2009 гг., Национальная галерея современного искусства Монголии

that it is reflected in his work. The works, which were considered by many people, were unique in that they distorted the image and symbolized the meaning and sexual symbolism. Impressionism also prevailed, and Allah Prima prevailed.

A total of 247 modern paintings were analyzed: abstract - 87, impressionism - 11, cubism - 12, fauvism -23 , surrealism - 25, expressionism - 7, neo-expressionism - 18, post-impressionism (synthetism, Pont Avena school) - 25, symbolism -18 , nabism -7 , animalism -6 , futurism -1 , pointilism -3 , primitivism -4 (pic. 9).

In a study of modern paintings created between 2000 and $2009,35 \%$, or the highest flow, was abstract.

\section{Conclusion}

Mongolian modern art has developed a lot since the twentieth century and has become a major one. As researchers, we need to study modern painting and contemporary art in detail. Therefore, it is an important topic at the right time. The following results have been obtained by studying the categories of modernism that are lacking in Mongolian art studies.

In modern paintings created in 1990-2000, abstract, post-impressionism and impressionism were more developed, while in 2000-2009, abstract, fauvism, surrealism, and symbolism were more developed. From here, Mongolian artists have created more abstract and symbolic paintings.

Before 1990, realism was widely produced, but since then, modernism has developed, and become a major trend.

An analysis of the evolution and classification of contemporary Mongolian art: the development of modern art, its history, and its conceptual classification was carried out This is the first study to analyze the contemporary works in the collection of the Mongolian Art Gallery.

Finally, 224 paintings were analyzed and the category was formed. This was of great importance to the gallery, and it was an honorable work for the public to understand the art.

\section{References}

1. Everdell, W. (1917). Modernism. New York.

2. Read, G. (1933). Art now. Chicago.

3. Sonomtseren, L. (1989). Mongolian fine art. Ulaanbaatar.,

\section{Список литературы}

1. Эверделл В. Модернизм. - Нью-Йорк, 1917.

2. Рид Г. Искусство сейчас. - Чикаго, 1933.

3. Сономцерен Л. Монгольское изобразительное искусство. - Улан-Батор, 1989.

\section{Информация об авторе}

Тумур-Очир Сэлэнгэ - аспирант Монгольского государственного педагогического университета, Улан-Батор, Монгольская Народная Республика.

\section{Information about the author}

Selenge Tumur-ochir - postgraduate student at Mongolian State University of Education, Ulaanbaatar, Mongolian People's Republic.

Поступила в редакцию / Received 21.05.2021

Принята к публикации / Accepted 19.09.2021

Опубликована / Published 29.09.2021 